\title{
Hypercalcaemia in alphacalcidol therapy
}

\author{
C. R. PATERSON \\ D.M., M.R.C.Path.
}

University Department of Biochemical Medicine, Ninewells Hospital, Dundee DD1 9SY

\begin{abstract}
Summary
Three women with hypoparathyroidism are described who developed severe symptomatic hypercalcaemia while being treated with alphacalcidol (1 $\alpha$-hydroxycholecalciferol; One-Alpha). One sustained permanent renal damage. Alphacalcidol may have advantages over calciferol in its speed of action but poisoning may be more likely to occur. Frequent follow-up checks on the plasma calcitim is needed for any patient on alphacalcidol. For long-term management calciferol may still be the drug of choice.
\end{abstract}

\section{Introduction}

For many years the standard treatment of hypoparathyroidism has been vitamin $D$ (calciferol) in large doses-generally $0.5-2 \mathrm{mg}$ daily. This contrasts with the physiological requirement which, in adults, is of the order of $2.5 \mu \mathrm{g} /$ day. In recent years it has been shown that hypoparathyroidism responds to microgram doses of the vitamin $\mathrm{D}$ metabolite 1,25-dihydroxycholecalciferol $\left(1,25(\mathrm{OH}) \mathrm{D}_{3}\right)$ or similar doses of $1 \alpha$-hydroxycholecalciferol (alphacalcidol) which is converted in the liver to $1,25(\mathrm{OH})_{2} \mathrm{D}_{3}$ (Russell et al., 1974; Kooh et al., 1974; Neer, Holick and Potts, 1975; Davies et al., 1977). Alphacalcidol is now available commercially. It is claimed to have advantages over native vitamin $D$ (calciferol) in the management of hypoparathyroidism in that the hypocalcaemia is corrected more rapidly, and in that should hypercalcaemia develop, this is corrected quickly by withdrawal of the drug (Kanis and Russell, 1977). Three patients are now reported who became hypercalcaemic on alphacalcidol, and the causes of this are sought.

\section{Patients}

The 3 patients were all women and all had hypoparathyroidism after thyroid surgery. One (case one) had been previously treated with dihydrotachysterol but was transferred to alphacalcidol as she was persistently hypocalcaemic. The other 2 had been treated with alphacalcidol from the time of diagnosis Details of the patients are given in Table 1 .

In case one the alphacalcidol $(2 \mu \mathrm{g} /$ day $)$ was started and the patient sent home the next day. She was not seen until one month later when she was readmitted as an emergency with weakness, lassitude and anorexia. While the plasma calcium fell rapidly after treatment with i.v. fluids and steroids, she had persistent renal impairment, as measured by the plasma creatinine, which was not present before the episode of hypercalcaemia. In case 2 the alphacalcidol was started in the immediate postoperative period, and the plasma calcium rose steadily over 2 months to $2.88 \mathrm{mmol} / \mathrm{l}$. No action was taken when this high value was reported. She was admitted as an emergency 2 weeks later because of weakness, anorexia and confusion. The alphacalcidol was stopped and steroids administered; the plasma calcium fell to normal within a week. In case 3 alphacalcidol $(2 \mu \mathrm{g}$ daily) was started one week after thyroid surgery, and within 4 days the plasma calcium had risen to $2.37 \mathrm{mmol} / \mathrm{l}$. One week later the value was $2.58 \mathrm{mmol} / \mathrm{l}$ and the patient was not seen again for a further 2 weeks, by which time she was vomiting, and complained of muscle weakness; the plasma calcium was $3.82 \mathrm{mmol} / \mathrm{l}$.

\section{Discussion}

Alphacalcidol is a valuable new drug for the management of hypoparathyroidism but its limitations need to be recognized. Like calciferol itself its effect is cumulative (Brickman et al., 1976), and the full response to a given dose may not be seen for several weeks. As with calciferol the key to the prevention of hypercalcaemia is constant vigilance; as with calciferol a plasma calcium level rising rapidly within the normal range is a signal for stopping the drug (Paterson, 1980). The speed of action of alphacalcidol is such not only that normocalcaemia may be achieved more rapidly than with calciferol-but hypercalcaemia may also supervene more rapidly. With calciferol it is usually suggested that patients should be seen not less often than once every 4 months even when the plasma calcium is apparently stable (Paterson, 1980; Davies and Adams, 1978). A corresponding period for alphacalcidol is probably one month. 
TABLE 1. Biochemical findings in patients with alphacalcidol poisoning

\begin{tabular}{|c|c|c|c|c|c|}
\hline Case & $\begin{array}{l}\text { Plasma calcium } \\
(\mathrm{mmol} / \mathrm{l})\end{array}$ & $\begin{array}{l}\text { Plasma phosphate } \\
\text { (mmol/l) }\end{array}$ & $\begin{array}{l}\text { Plasma urea } \\
(\mathrm{mmol} / \mathrm{l})\end{array}$ & $\begin{array}{l}\text { Plasma creatinine } \\
(\mu \mathrm{mol} / \mathrm{l})\end{array}$ & $\begin{array}{c}\text { Plasma creatinine aft } \\
\text { correction of } \\
\text { hypercalcaemia } \\
(\mu \mathrm{mol} / \mathrm{l})\end{array}$ \\
\hline $\begin{array}{l}1 . \\
2 . \\
3 .\end{array}$ & $\begin{array}{l}3 \cdot 42 \\
3 \cdot 41 \\
3 \cdot 82\end{array}$ & $\begin{array}{l}1 \cdot 67 \\
1 \cdot 28 \\
1 \cdot 39\end{array}$ & $\begin{array}{r}20 \cdot 9 \\
10 \cdot 2 \\
9 \cdot 8\end{array}$ & $\begin{array}{c}372 \\
\overline{181}\end{array}$ & $\begin{array}{r}216 \\
92 \\
82\end{array}$ \\
\hline
\end{tabular}

The controlling step in normal vitamin D metabolism is the second hydroxylation (the $1 \alpha$-hydroxylation) which takes place in the kidney. By the use of alphacalcidol this key step is bypassed and accumulation of 1,25-dihydroxycholecalciferol is likely to occur. Although alphacalcidol has only been available for a short time, some of the practical difficulties have become clear. For example the administration of anticonvulsants diminishes the response to alphacalcidol (Lewin et al., 1978). There is some evidence too, that alphacalcidol may impair renal function even in normal people (Compston, Horton and Laker, 1979).

While alphacalcidol may be valuable for the early treatment of the hypoparathyroid patient with symptoms (Gertner, Hodsman and Neuberger, 1976), it is likely that calciferol will remain the drug of choice in long-term maintenance.

\section{Acknowledgment}

I am indebted to Professor G. H. Bell for comments on the text.

\section{References}

Brickman, A.S., Coburn, J.W., Friedman, G.R., Okamura, W.H., MASSRY, S.G. \& NoRMaN, A.W. (1976) Comparison of effects of $1 \alpha$-hydroxy-vitamin $D$ and 1,25-dihydroxyvitamin D in man. Journal of Clinical Investigation, 57, 1540.
Compston, J.E., Horton, L.W.L. \& LAKer, M.F. (1979ి Vitamin-D analogues and renal function. Lancet, $\mathbf{i}, 386 . \overrightarrow{2}$ Davies, M. \& ADAMS, P.H. (1978) The continuing risk of vitamin-D intoxication. Lancet, ii, 621.

Davies, M., Hill, L.F., TAYlor, C.M. \& Stanbury, S.W (1977) 1,25-dihydroxycholecalciferol in hypoparathyo roidism. Lancet, i, 55.

GerTner, J.M., Hodsman, A.B. \& Neuberger, J.N. (197\% 1-alpha-hydroxycholecalciferol in the treatment of hypdir calcaemic psychosis. Clinical Endocrinology, 5, 539.

KANIS, J.A. \& RuSSELl, R.R.G. (1977) Rate of reversal of hypercalcaemia and hypercalciuria induced by vitamin and its $1 \alpha$-hydroxylated derivatives. British Medical Journat $1,78$.

KoOH, S.W., Fraser, D., Deluca, H.F., Holick, M.Fg Belsey, R.E., Clark, M.B. \& Murray, T.M. (1975), Treatment of hypoparathyroidism and pseudohypoparathyroidism with metabolites of vitamin D: evidence for impaired conversion of 25 -hydroxyvitamin D to $1 \alpha-25$ dihydroxyvitamin D. New England Journal of Medicin $\overrightarrow{\mathrm{E}}$ 293, 840.

Lewin, I.G., Papapoulos, S.E., Tomlinson, S., He $\frac{0}{\mathrm{Y}}$ G.N. \& O'RIORDAN, J.L.H. (1975) Studies of hypopira? thyroidism and pseudohypoparathyroidism. Quartir Journal of Medicine, 47, 533.

NeER, R.M., Holick, M.F. \& Potrs, J.T. (1975) Effects $1 \alpha$-hydroxy-vitamin $D_{3}$ and 1,25-dihydroxy-vitamin $D_{3}$ on calcium and phosphorus metabolism in hypoparath $\mathbb{D}$ roidism. Metabolism, 24, 1403.

PATERSON, C.R. (1980) Vitamin-D poisoning: survey $\overrightarrow{\vec{\sigma}}$ causes in 21 patients with hypercalcaemia. Lancet, $\mathbf{i}, 116 \overline{4}$

Russell, R.G.G., Smith, R., Walton, R.J., Preston, C? Basson, R., Henderson, R.G. \& Norman, A.W. (1978 1,25-dihydroxycholecalciferol and $1 \alpha$-hydroxycholecalciferol in hypoparathyroidism. Lancet, ii, 14. 